\title{
THE EU IN LIBYA AND THE COLLAPSE OF THE CSDP
}

\section{Ludovica Marchi*}

\begin{abstract}
This article aims at exploring the unwillingness of the EU member states to sponsor a Common Security and Defence Policy (CSDP) joint action within the EU framework as a response to the violence against civilians which erupted in Libya in 2011. It investigates the attitudes of Britain, France, Germany and Italy, as representative of the EU/27, toward the developments in Libya and a possible CSDP's crisis-management operation. It discusses the assumption that the CSDP was prey to the member states' wishes. The article avails itself of official documents from the UNSC, the European Union, EU laws, EU officials and prime ministers' speeches, together with several interviews.
\end{abstract}

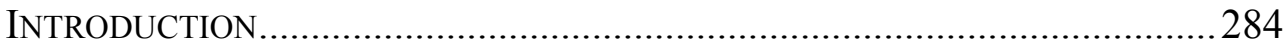

I. The PoliticAl CONTEXT OF THE CRISIS ........................................... 285

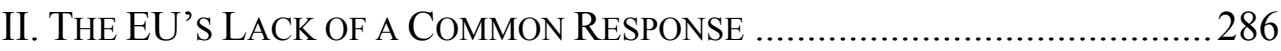

III. REACTION TO LIBYA AND TO A POSSIBLE CSDP'S OPERATION FROM

SOCIETY IN BRITAIN, FRANCE, ITALY AND GERMANY .............................28

IV. REACTION TO A POSSIBLE CSDP'S OPERATION FROM EUROPEAN

LEADERS: FRANCE, BRITAIN, GERMANY, ITALY AND THE EU ...................228

V. A MISSED OPPORTUNITY ............................................................ 291

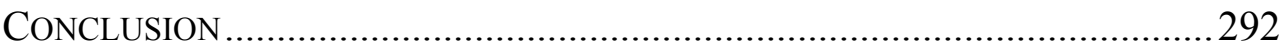

\section{INTRODUCTION}

In February 2011, Colonel Gaddafi's use of force against civilians generated a severe crisis in Libya. A collective action was deemed necessary to stop violence. On 31 March, according to UNSC Resolution 1973, a crisis management mission was launched by NATO, the Unified Protector Operation. France, Britain and the US, with the support of American airpower and the Arab and European allies, participated in the collective action. The operation was a coalition of the willing, from which the US military, later, withdrew as agreed within the coalition. This article deals with the EU's non-development of a crisis management intervention via its Common Security and Defence Policy (CSDP) as a response to the emergency situation. The member states could have taken the initiative within the EU framework instead of leaving this to NATO. After a decade

\footnotetext{
${ }^{*}$ Ludovica Marchi, Ph.D., (pen name of Ludovica Marchi Balossi Restelli), international relations political scientist, Visiting Fellow at the Centre for International Studies, Department of International Relations, London School of Economics and Political Sciences, London (UK). Research field: European Union's External Relations.
} 
of rapid development in terms of structure and deployment, the CSDP could have been operational in Libya. This article supports the assumption that the CSDP was prey to the member states' wishes. It aims to offer an insight into the perceived unwillingness of the EU member states, specifically Britain, France, Germany and Italy as representative of the EU/27, to sponsor a joint action within the EU framework, as a reaction to the Libyan crisis in 2011. It avails itself of official documents from the UNSC, the European Union, EU laws, EU officials and prime ministers' speeches, together with several interviews.

\section{The Political Context of THE CRisis}

It is worth remembering that, a few days after the crisis arose in Libya, on 21 February, the 27 EU foreign ministers convened in the Council of the European Union, in Brussels, and requested an end to the violence. Shortly afterwards, France, Germany and The Netherlands proposed sanctions, whereas Malta, Cyprus and Italy were unwilling to endorse the proposal. In late February, the then Britain's Prime Minister Cameron declared that the United Kingdom was preparing to arrange a no fly zone, possibly under NATO's coordination. France expressly stated that it was keen to use NATO's military command to "plan and execute air operations". However it strongly believed that the North Atlantic Alliance should take no political control of the overall military operation. This would have alienated the Arab countries. $^{1}$

At the European Council meeting of 11 March, the EU states were addressed by France to recognise the Benghazi-based Transitional National Council (TNC). The previous day, former France's President Sarkozy made a unilateral recognition of the TNC. ${ }^{2}$ Shortly afterwards, on 17 March, the UN Security Council approved the no-fly zone over Libya; it authorised all of the necessary measures to protect civilians. ${ }^{3}$ Sarkozy called a summit on Libya, in the French capital on 19 March. The meeting was tasked with organising the political guidance of the operation authorised by the UN. It was agreed with former America's President Obama that the first offensive action would be conducted by the US. With the Operation Odyssey Dawn, the US would nullify Libya's air defence system. Soon after having

\footnotetext{
1 "We are not at war", says Prime Minister Fillon (France24, International News, 24 March 2011), available at http://www.france24.com/en/20110322-france-not-war-libya-fillon-prime-ministergaddafi- military-intervention-un-resolution.

${ }^{2}$ The Politics Behind France's Support for Airstrikes on Libya (EurActiv, 11 March 2011), available at www.euractiv.com/...europe/politics-france-support-airstrik-.

${ }^{3}$ Resolution (1973) Security Council SC/10200 (17 March 2011).
} 
achieved that aim, NATO would replace the American leadership. Such an arrangement was making clear that the direction of the operation was under non-USA authority. ${ }^{4}$

On 20 March, French fighter jets opened fire on Gaddafi's troops. The collective action that ensued, allowed by Resolution 1973, the Unified Protector Operation, was led by NATO. As the US retreated, attacks on ground targets were undertaken by the French, British, Italian, Danish, Belgian, Canadian, Emirati, Qatari and Norwegian armies. The EU's lack of response to Libya is perceived as the result of the eroded influence of the EU structures, which have been affected by the nationalism of the member states. The latter's unwillingness to sponsor a joint action within the EU framework was the emerged outcome.

\section{THE EU'S LACK OF A COMMON RESPONSE}

Not that a discussion was eluded by the EU states on the matter of whether a military operation could be taken as an initiative of the CSDP within the European structures. However, there was no sign of the "ambition in the field of military crisis management" that some Swedish defence ministers had previously predicted for the EU. ${ }^{5}$ Nor any indication surfaced regarding the so-called "tarzan" narrative, which the EU had constructed in the first decade of the twenty-first century. ${ }^{6}$

As late as 12 April, at a meeting of EU foreign ministers in Luxembourg, a debate on whether the CSDP should intervene with armed forces occupied the agenda of the EU states. The meeting was held after the European Council had agreed, on 1 April, to the EUFOR Libya CSDP military mission. This one was anchored to the United Nation's request to intervene in support of humanitarian assistance operations. ${ }^{7}$ An operational plan was needed for the military humanitarian intervention. The discussion on that matter, in Luxemburg, unveiled the contrasting positions of the foreign ministers. In particular, the claim emerged that the UN retained access to Misrata, which was under siege by Gaddafi's forces, and an EU military action would have jeopardised the UN endeavours. Also, the

\footnotetext{
${ }^{4}$ Jolyon Howorth, The European Union IN (IN) Action: Brussels AND the ARAB Spring (2011), available at http://acdis.illinois.edu/assets/docs/615/articles/TheEuropeanUnioninInActionBrussels andtheArabSpring.pdf.

${ }^{5}$ Katarina Engberg, To Intervene or Not to Intervene? The EU and the Military Option in the Lebanon War of 2006, 11(4) PeRSPECTIVES ON EUROPEAN Politics AND SOCIETY 408 - 428 (2011).

${ }^{6}$ T. Trine Flockhart, "Me Tarzan-you Jane": The EU and NATO and the Reversal of Roles, 12(3) PERSPECTIVES ON EUROPEAN POLITICS AND SOCIETY 263-282 (2011).

${ }^{7}$ Council Decision 011/210/CFSP, EU Military Operation in Support of Humanitarian Assistance Operations in Libya, OfFICIAL JouRnal OF THE EUROPEAN UNION (5 April 2011).
} 
contention was advanced by the Italians that they could not understand the need for a military intervention to deliver humanitarian aid. The argument, outlined by others, that the deployment of forces was driven by a desire to demonstrate that the EU had a military planning capacity, distinct from that of NATO, was also aired. The indication that a military intervention was the only possible way to halt Gaddafi was, definitely, made. Concerned about the time-consuming decision to agree on when and how to end the military mission was also reportedly evident at the meeting. Apparently, disagreement about the EU being divided among the "do-gooders" and the "warriors" was impossible to restrain. In the end, a high level UN aid-andrelief official's letter to the then EU High Representative Ashton finally answered these objections. The letter disclosed the reservations about providing military support for a humanitarian mission. ${ }^{8}$ Hence, the military operation prospect vanished.

By contrast, a few days after the EU foreign ministers met in Luxemburg, former France's President Sarkozy and former Britain's Prime Minister Cameron underwrote a letter. The missive was signed also by the former US President Obama and was published in the New York Times. It declared that "Gaddafi must go and go for good".

\section{REACTION TO LIBYA AND TO A POSSIBLE CSDP'S OPERATION FROM SOCIETY IN BRITAIN, FRANCE, ITALY AND GERMANY}

What was the reaction to the Libyan emergency by the member states and their societies at the time of the crisis? In Britain, society was more prone to repatriate their share of policy from Brussels than to tie in with the CSDP and its military. ${ }^{10}$ Concern about becoming embroiled in excessive bureaucracy and, perhaps on occasions, being obliged to depend on the policies and choices made by others ${ }^{11}$ did not favour a friendly vision of the CSDP, even with regard to Libya.

In France, society was largely behind Sarkozy's military initiative, with Parliament accepting the notion of a new era in the Mediterranean. Parliament has not rejected Sarkozy's assertive role under the claim of

\footnotetext{
${ }^{8}$ Toby Vogel, Split over Military Mission to Deliver Aid, EuROPEAN VoICE (14 April 2011), available at http:// www.europeanvoice.com/article/imported/split-over-military-mission-to-deliveraid/70808.aspx.

${ }^{9}$ Libya's Pathway to Peace, THe New York Times (14 April 2011), available at http://www.nytimes.com/2011/04/15/opinion/15iht-edlibya15.html.

${ }^{10}$ Cameron Rules Out EU Referendum, FinANCIAL Times, (21 May 2012).

${ }^{11}$ Author's Interview with a Senior British official (London, November 2012).
} 
further action in the CSDP. ${ }^{12}$ If questioned about the feasibility of a CSDP accomplishment in Libya, the French would respond that, above all, rapidity of action was important. ${ }^{13}$

In Italy, society was, above all, concerned with former Prime Minister Berlusconi's tardy reaction rather than with deserting the CSDP. However, soon after the crisis developed, Italian national broadcasters, such as La7, interviewed political observers. On those occasions, reference to the existence of a process to be put into motion especially in these circumstances, the CSDP, was made. To other political observers, the fact that "European nations" conducted the military intervention under the NATO's lead was, by itself, a synonym for European unity. They rejected any preoccupation for bypassing the CSDP. ${ }^{14}$

In Germany, society questioned the government's non-alignment with its traditional allies rather than its weak connection with the CSDP as a civil-military actor. ${ }^{15}$ Yet, the usual emphasis on "non-attachment to the military CSDP" was downplayed as an approach which performed well with a certain electorate. It was expressed in Berlin's Bundestag also concerning the case of Libya. ${ }^{16}$

\section{REACTION TO A POSSIBLE CSDP'S OPERATION FROM EUROPEAN LEADERS: FRANCE, BRITAIN, GERMANY, ITALY AND THE EU}

Investigating the national and European leaders' conduct in response to the crisis in terms of supporting a CSDP civil-military operation, further details emerge. In France, former President Sarkozy's personal standing was at stake in view of the relatively soon national contest for the presidency (April 2012). France generally held the initiative within the CSDP, inspired by "Europe de la defence" ideas. On this occasion, it is unthinkable that Sarkozy did not wish to avoid suppressing France's own interests and influence in Africa in the pursuit of a minimal European consensus. ${ }^{17}$ On previous occasions, France had already experienced the extent to which the CSDP lacked promptness of action. Regarding Chad, it had to make efforts

\footnotetext{
${ }^{12}$ French Parliament Debates Libya Military Mission, FranCe 24 InTernational News (22 March 2011), available at www.france24.com/.../20110322-french-parliament-debates-li.

${ }^{13}$ Author's Interview with a French Public Official (Rome and Lyon, May 2011).

${ }^{14}$ Author's Interview with an Italian Political Scientist (Rome, RomaTre University, October 2011).

${ }^{15}$ Blast from the Past has Merkel on the Defensive, August 26, DAS SPIEGEL (18 March 2011), available at www.spiegel.de/.../letter-from-berlin-blast-from-the-past-has-merkel-.

${ }^{16}$ Author's Interview with a German Security Analyst (Cardiff and Oxford, March 2013).

${ }^{17}$ Jean-Yves Haine, CSDP is dead. Long live CSDP!, XIX(1)The Bulletin OF THE Program IN ARMS CONTROL, DISARMAMENT, AND INTERNATIONAL SECURITY 11-16 (University of Illinois at Urbana-Champaign, 2011).
} 
to convince the other member states to participate in the EU's operation. ${ }^{18}$

The project for an integrated Mediterranean area had been the focus of Sarkozy's attention since 2008, reviving the idea of a Union of the Mediterranean. In March 2011, during the Libyan crisis, the then Prime Minister Fillon claimed, in the French Parliament, that "France want[ed] to see a new era in the Mediterranean region". ${ }^{19}$ Sarkozy had already wasted time, and lost the opportunity for initiatives, during the previous challenge of the Tunisian unrest. His failure to respond to that crisis already overloaded his government with the dismissal of the Foreign Minister. He needed rapidity of action, and the CSDP was not congenial towards Sarkozy's decision to oppose violence in Libya.

In Britain, former Prime Minister Cameron's decreasing domestic consensus on the uneasy handling of his coalition government challenged his position and reputation. Much of Cameron's efforts were aimed at raising his standing by reinforcing his party. Perhaps Blair, the previous British Prime Minister, would have sought an initiative by his country in Europe, leading the CSDP to calm the violence in Libya, believing it to be a positive asset. Through his attempts to broaden his political basis, however, Cameron reignited Britain's European political controversies.

The promise of an in-out referendum on Europe, in 2017, if the Conservatives win the next general election had been aired as manifesto. Cameron could inconceivably be the promoter of a security operation in Libya within the CSDP. Yet, he was ready to intervene in Libya even without a UN resolution. The then European Security and Defence Policy was never mentioned in Britain's 2010 national security strategy document. Soon after his election in May 2010, Cameron signed with Sarkozy a British defensive treaty with France, in November 2010. On that occasion, Cameron indicated that, through that agreement, the two leaders could "do more things alone as well as together". ${ }^{20}$ By using the management of the Libyan crisis as an occasion for the joint operational and political leadership of these two states, ${ }^{21}$ instead of passing it to the EU, Cameron aimed to increase his reputation at home.

In Germany, not very differently from the European counterparts, Chancellor Merkel was concerned about not jeopardising her position within

\footnotetext{
${ }^{18}$ Jean-Yves Haine, The Failure of a European Strategic Culture-EUFOR Chad: The Last of Its Kind?, 32(3) CONTEMPORARY SECURITY POLICY 582-603 (2011).

19 "We are not at war", says Prime Minister Fillon, Op. Cit.

${ }^{20}$ Britain and France Sign Landmark 50-Year Defence Deal, THE GuARDIAN, (2 November 2010), available at www.theguardian.com $>$ News $>$ Politics $>$ Defence policy.

${ }^{21}$ Jorge Benitez, Europe Needs a Military Avant-Garde, ATLANTIC CounCIL, (3 April 201), available at www.acus.org/ natosource/europe-needs-miliary-avant-garde.
} 
the party. Becoming involved in any process backing deployment was raising the question of how the electorate would react to it, in the upcoming elections in some states (18 September 2011). The Chancellor also faced parliamentarian opposition to her plans for the European Financial Stability Facility. ${ }^{22}$ Her party's power was expected to be eroded. Merkel could not sponsor the CSDP to play a role in Libya. Apparently, the German "ontological" problems with security countered the "military connection".

This position was, however, paradoxical. As an opinion poll conducted on 22 June 2011 in EU countries and the US revealed, Germany was the first after the primacy of France to underwrite the military operation which actually took place outside the EU framework. ${ }^{23}$ A paradox was also the much-talked abstention, on 17 March, from UNSC Resolution 1973 imposing the no-fly zone, which the EU also supported. Convinced human rights champion Chancellor Merkel aligned Germany with Russia and China, unquestionably no great human rights supporters. These paradoxes and the inability to compromise show that concessions, including championing the CSDP, were endangering Merkel's domestic position.

In Italy, former Prime Minister Berlusconi focused on avoiding, as far as possible, the disastrous personal impact that the situation in Libya was threatening to generate. His party and government had several consequences of the crisis to face. The development of an EU/CSDP operation was not the focus. In 2008, Berlusconi had agreed with Tripoli a friendship and cooperation treaty. The commitment that Italy would not consent to the use of its territory for any "hostile act" (or engage in "direct or indirect" military action) against Libya was made.

The former prime minister feared that this conflict would have a negative impact on many Italian companies, which were partly owned by the Libyan government (e.g. FIAT SpA and UniCredit SpA). The Italian national energy corporation, Eni SpA, had been active for more than fifty years in Libya. More than 1,300 Italian workers had to be rescued from that country prior to any military action being taken. ${ }^{24}$ Berlusconi was concerned about the flow of Libyan migrants into Italy that, together with other problems, would damage his political party's foundation. In addition, a quarter of Italy's crude oil requirements where being supplied by Libya. This was a further motive confirming that any reference to military CSDP

\footnotetext{
${ }^{22}$ Blast from the Past has Merkel on the Defensive, Op. Cit.

${ }^{23}$ Roberto Menotti, Verso i 100 giorni della NATO in Libia (Aspenia, 22 June 2011), available at $\mathrm{http}: / / \mathrm{www}$.aspeninstitute.it/aspenia-online/article/verso-i-100-giorni-della-nato-libia.

${ }^{24}$ Comunicazioni Del Governo Sulla Crisi libica 20 (Italian Government, Frattini, March 24, 2011).
} 
activity in Libya was far from what Berlusconi wanted.

At the EU institutional level, also former EU High Representative Ashton appeared making no effort to enhance the reputation of the CSDP to challenge authoritarian Libya. Ashton's attitude had not helped to generate support and make the EU/CSDP more influential. Ashton's assertion, at the Corvinus University (February 2011), that the strength of the EU lay (paradoxically) in its inability to throw its weight around was a sign that Ashton wished to distance herself from a CSDP military mission. ${ }^{25}$

Ashton was apparently obsessed with the problem of the "reality of 27 member states who are sovereign, who believe passionately in their own right to determine what they do, particularly in the area of defence". ${ }^{26}$ At the European Council emergency meeting of 11 March 2011, Ashton's views prevailed when the EU leaders signed a communique that omitted any mention of the no-fly zone that was keenly sponsored by France and Britain. The communiqué sparked a furious debate. In London, "should [Baroness Ashton] not serve the member states of the European Union rather than pretending to lead them?" was the prevalent MPs' accusation, which engaged former Prime Minister Cameron in a defensive debate in the Commons. ${ }^{27}$ Ashton was influenced, if not taken hostage, by the politics of Britain and France, with Cameron and Sarkozy covertly instructing her not to interfere in the military decision-making. ${ }^{28}$

\section{A MiSSED OPPORTUNITY}

Taking the political control and strategic direction of the NATO military operation if the Berlin-Plus mechanisms had been used instead of leaving it to NATO was a missed opportunity. Not possessing the necessary military capabilities was watched with "anxiety" on the other side of the Atlantic. Also, it was branded by some as "the European culture of demilitarization". ${ }^{29}$ This hurdle was, nonetheless, lowered by the US granting assistance. In fact, the US support was important in the light of the

\footnotetext{
${ }^{25}$ CAtherine Ashton, A World Built on Co-Operation, Sovereignty, Democracy AND STABILITY (Corvinus University, Budapest, 25 February 2011), available at http://europa.eu/rapid/pressReleasesAction.do?reference=SPEECH/11/ 126.

${ }^{26}$ Europe's Foreign POLICY In Line OF Fire OVER Libya (24 March 2011), available at down.com/.../europes- foreign-policy-in-line-of-fire-over-lib.

${ }^{27}$ David Cameron Mocks Cathy Ashton after “Rogue Briefing”, THE GUARDIAN (15 March 2011), available at www.theguardian.com>News>Politics>Wintour and Watt blog.

${ }^{28}$ Author's Interview with an EEAS Official (Brussels, November 2012).

${ }^{29}$ US Secretary of Defence, Robert Gates, speech "NATO Strategic Concept Seminar" (National Defense University, Washington D.C., 23 February 2010), available at www.defense.gov/speeches/speech.aspx? speechid=1423.
} 
lack of aircraft carriers, smart munitions and enablers of modern warfare, surveillance and air tanking. ${ }^{30}$

The kind of setting of a Europe-led NATO command configuration was not new. It was defined, in the 1990s, as the European Security and Defence Identity, namely a NATO mission, conducted by the Europeans operating through US military resources. It was surpassed, in 2002, by the Berlin Plus arrangement, which allowed the CSDP to use NATO (i.e. US) assets to handle an operation without the involvement of US forces. ${ }^{31}$ The Berlin Plus mechanisms were successfully used in Operation Concordia in Macedonia, in 2003. ${ }^{32}$ They were indeed offering a more "European" option to mark the operation in Libya. Specifically, even though the military action was implemented under NATO command, the member states' choice to resort to the Berlin-Plus procedures would have allowed the CSDP to undertake strategic control of the military action.

\section{CONCLUSION}

This article aimed to investigate the reluctance of the EU member states to promote a Common Security and Defence Policy joint action within the EU framework to stop the violence against civilians in Libya in 2011. Its outline of the political context of the crisis showed how the action evolved along a course that differed from the use of the mechanisms foreseen by the European Union laws. This allowed the formation of a crisis management intervention by the EU/Common Security and Defence Policy that contributed toward calming down violence such as that which developed at Europe's southern boundary. The article's discussion of the way in which the EU member states debated the options on the table, while at the European Council, made clear their several excuses for opposing an intervention with armed forces from the CSDP. Also, the overview of the reactions to Libya's developments both from societies and the member states' leaders in Britain, France, Germany and Italy, as representative of the EU/27, highlighted the evidence that the CSDP raised no interests on that occasion. Refusing to follow the policy choices made by others, paying excessive importance to the rapidity of action, attempting to broaden their political basis, harboring preoccupations regarding the upcoming political elections, and, not last being overcome by the fear of a negative impact on

\footnotetext{
${ }^{30}$ Nick Witney, How to Stop the Demilitarisation of Europe, ECFR POLICY BrIEF (2011), available at www.ecfr.eu/page/-/ECFR40_DEMILITARISATION_BRIEF_AW.pdf.

${ }^{31}$ Jolyon Howorth, The European Union in (in)action, Op. Cit.

${ }^{32}$ Catriona Mace, Operation Concordia: Developing a "European Approach to Crisis Management", 11(3) InTERnAtional PEACEKEEPING 474—490 (2004).
} 
the flourishing commercial activities with Libya, were testified, by this article, as multiple causes which militated against the CSDP's action. Also, the role played by the former EU High Representative emerged, from the analysis, as submissive to the member states' policy, particularly that of Britain and France. The article's discussion of the member states' unexplored opportunity to employ the Berlin-Plus arrangement that would have allowed the CSDP, supplemented by US assets, to take strategic control of the military action, confirmed their apparent low inclination toward developing the CSDP's policy. The article proved the truth of the assumption that the CSDP was being prey to the member states and their wishes regarding the specific circumstance of responding to the troubles that arose in Libya. It demonstrated that the lack of a common response via the CSDP was mainly influenced by the EU states' domestic affairs. Ultimately, national preoccupations, concerns and interests gained the upper hand, expressed their disinterest in a common action within the EU framework and conveyed a sense of a collapsed CSDP. 